\title{
Improving Food Security by Adapting and Mitigating Climate Change-Induced Crop Pest: The Novelty of Plant-Organic Sludge in Southern Nigeria
}

\section{Chukwudi Nwaogu}

\section{Contents}

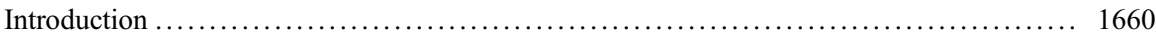

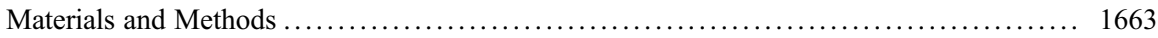

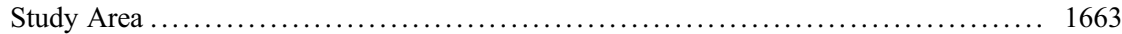

Experimental Design, Yam Cultivation, and Treatments ....................... 1666

Soil Sampling and Chemical Properties Analyses ............................ 1668

Termites Sampling ...................................................... 1669

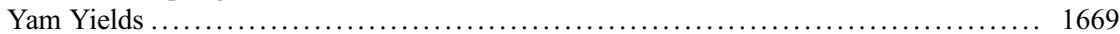

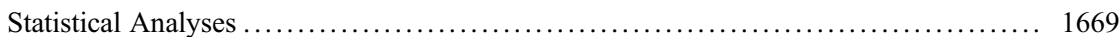

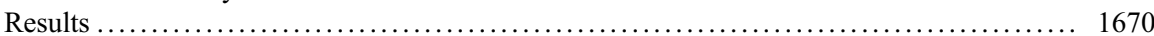

Soil Chemical Properties ................................................ 1670

Yam Tuber Yield and Termites ......................................... 1670

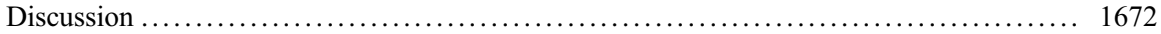

Soil Chemical Properties ............................................... 1672

Yam Tuber Yield and Termites .......................................... 1676

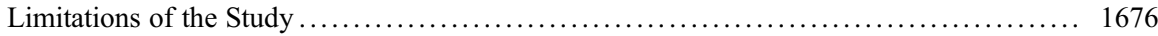

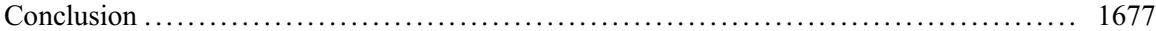

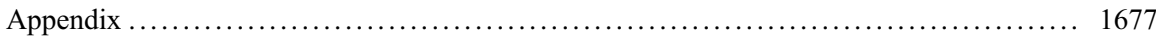

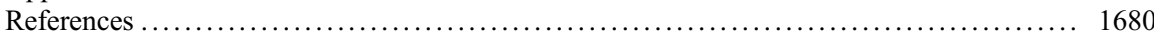

This chapter was previously published non-open access with exclusive rights reserved by the Publisher. It has been changed retrospectively to open access under a CC BY 4.0 license and the copyright holder is "The Author(s)". For further details, please see the license information at the end of the chapter.

C. Nwaogu (ه)

Department of Forest Protection and Entomology, Faculty of Forestry and Wood Sciences, Czech University of Life Sciences, Prague 6-Suchdol, Czech Republic

Department of Environmental Management, Federal University of Technology, Owerri, Nigeria

Department of Ecology, Faculty of Environmental Sciences, Czech University of Life Sciences, Prague 6-Suchdol, Czech Republic

e-mail: cnwaogu@gmail.com 


\section{Abstract}

Climate change is a global issue threatening food security, environmental safety, and human health in tropical and developing countries where people depend mainly on agriculture for their livelihood. Nigeria ranks among the top in the global yam production. It has the largest population in Africa and has been able to secure food for its growing population through food crops especially yam. Unfortunately, the recent increase in termites' colonies due to climate change threatens yam yield. Besides harming man and environment, pesticides are expensive and not easily accessible to control the pests. This prompted a study which aimed at applying a biotrado-cultural approach in controlling the termites, as well as improving soil chemical properties and yam production. The study hypothesized that Chromolaena odorata and Elaeis guineensis sludge improved soil nutrient and yam yield and consequently decreased termites' outbreak. In a randomized design experiment of five blocks and five replicates, five different treatments including unmanaged (UM), Vernonia amygdalina (VA), Chromolaena odorata (CO), Elaeis guineensis (EG) liquid sludge, and fipronil (FP) were applied in termites-infested agricultural soil. Data were collected and measured on the responses of soil chemical properties, termites, and yam yield to treatments using one-way ANOVA, regression, and multivariate analyses. The result showed that Chromolaena odorata $(\mathrm{CO})$ and EG treatments were the best treatments for controlling termites and increase yam production. Termites were successfully controlled in VA and FP treatments, but the control was not commensurate with yam production. The experiment needs to be extended to other locations in the study region. It also requires an intensive and long-term investigation in order to thoroughly understand (i) the influence of climate change on the termites' outbreak, (ii) the extent of termite damage to the crops, (iii) the impacts of climate change and variability on yam yields, (iii) the agricultural and economic benefits of the applied treatments, and (iv) the ecological and human health safety of the treatments.

\section{Keywords}

Climate change $\cdot$ Sustainable agriculture $\cdot$ Soil $\cdot$ Pest management $\cdot$ Termites $\cdot$ Elaeis guineensis · Vernonia amygdalina $\cdot$ Chromolaena odorata · Fipronil · Ikpo-Obibi

\section{Introduction}

Climate change has globally become a serious threat to environment and man especially in the areas of food security and rapid growing population. Though the impacts of climate change have no geographical boundary, yet the countries in sub-Saharan Africa tend to suffer more because of several reasons including socioeconomic, political, and ecological factors (Slingo et al. 2005; Kurukulasuriya et al. 
2006). The Assessment Reports of the Intergovernmental Panel on Climate Change (IPCC) urged that, even with the predicted climate change scenarios, extreme events may still occur with devastating effects in more vulnerable areas, causing severe long-term food insecurity (Boko et al. 2007; Christensen et al. 2007).

Yam (Dioscorea spp.) is a tuber crop which serves as a major staple food for about $34 \%$ of the world's population. In comparison to other tuber crops, yam is a vital source of essential minerals including carbohydrates, vitamins, proteins, and dietary fibers (Olajumoke et al. 2012). In 2004, the world's yam production was estimated at about 46.8 million metric tons, and West Africa accounted for more than two-third of this global production (Sartie et al. 2012). Nigeria ranks highest in yam production among the sub-Saharan African countries (CGIAR 2004). Yam is a highly preferred food crop in Nigeria because:

(i) It is one of the easiest and fastest food to be prepared in different flavor.

(ii) Yam tubers can be preserved for longer time (4-6 months) at ambient temperature unlike sweet potato (Ipomoea batatas L.) and cassava (Manihot esculenta). The sustainability of yam as a source of food for every household is high, even during the onset of the rainy season when food tends to be scarce, yam tubers will be available (Loko et al. 2015). Hence, yam is locally referred as "enyi nwa-ogbuenye na'uwu" meaning "the orphan's salvager in time of famine."

(iii) Economically, yam tubers are high sources of income for the indigenous farmers, and this helps to alleviate poverty (Olorede and Alabi 2013).

(iv) Socio-culturally, yam promotes the social life of the people: several festivals (such as New Yam Festival, Yam title coronation, and marriage) are celebrated by communities, groups, and individuals using yam (Osunde and Orhevba 2009).

During cultivation, yam has its tubers buried in the soil which is the habitat of most ant species especially termite. Termite (Isoptera) has been described as one of the yam tubers' main destructive fauna (Atu 1993; Loko et al. 2015). Common among the termite species that damage the yams are the Microtermes, Ancistrotermes, and Macrotermes (Loko et al. 2015). The damage consists of feeding and destruction of planted setts of yam (including tubers, leaves, stems), and yam staking materials, as well as release of methane (Zimmerman and Greenberg 1983). Yam tubers to be harvested are sometimes heavily tunneled in termite-infested soil because the Microtermes spp. seldom build colonies within tubers and create apparent hollows. In Nigeria, it has been reported that in soils with high termite infestation, farmers lose more than $5 \mathrm{t} \mathrm{ha}^{-1}$ of yam due to damage by termites (Atu 1993). However, in the tropics and subtropics, termite has been reported as litter decomposer, and a key player in soil formation (Richard et al. 2006; Belyaeva and Tiunov 2010), yet it degrades the soil quality (Devendra et al. 1998).

Globally, the net impact of climate change has been predicted to include increase in pest damage to agricultural resources (Lovett et al. 2005). In tropical Africa 
precisely, climate change has crucial role in the striving, reproduction, and cropdestructive ability of the pests by making the environment favorable for them. Due to variations in weather especially rainfall and temperature, termites' outbreak and infestation become acute. Studies have shown that an average annual rainfall and temperature below $100 \mathrm{~cm}$ and $27^{\circ} \mathrm{C}$, respectively, promote the survival and catastrophic impacts of the pest (Atu 1993; Richard et al. 2006; Belyaeva and Tiunov 2010). Though termites have been reported to be present throughout the year in most tropical countries of Africa (Wood 1995), their agricultural and economic damage tend to be exacerbated during periods of low rainfall (Ahmed et al. 2011). In the study conducted on the potential impact of climate change on termite distribution in Southern Zambia, Ahmed et al. (2011) found that after a drought, the number of pestiferous termite species increased drastically. Similarly, another study, performed in Uganda by Pomeroy (1976), demonstrated that the distribution of termites' mounds was significantly correlated with temperature and that large termite mounds were absent in areas of lower temperature and high rainfall. Kemp (1955) observed that climate was the principal factor determining the distribution of termites in Northeastern Tanganyika (Tanzania). Farmers in Nigeria, Uganda, and Zambia have reiterated that termite problems are more serious now than in the past (Atu 1993; Sekamatte and Okwakol 2007; Sileshi et al. 2009). Damage by the pests is higher during dry periods than in periods of regular rainfall (Logan et al. 1990). The rapid increase in termite damage might also be attributed to climate change-induced drought. For example, in the last two to three decades, drought associated with El Niño episodes has become more intense and widespread in Africa (Harrington and Stork 1995). Many studies have previously established strong nexus among climate change, termites invasion, and damage to agricultural resources (Jones 1990; Kemp 1955; Logan et al. 1990; Nkunika 1998; Bignell and Eggleton 2000; Eggleton et al. 2002; Ahmed and French 2008; Ahmed et al. 2011; Beaudrot et al. 2011; RoulandLefèvre 2011; Buczkowski and Bertelsmeier 2017).

Ikpo-Obibi is one of the important yam-producing communities in Nigeria with more than $80 \%$ of the population engaging in agriculture. It is pathetic to report the farmers' ordeal with the climate change-induced termites in the process of yam production. Despite the nutritional and socioeconomic benefits of yam, the termites' attack poses great challenge.

In terms of the control measures, most farmers in Africa have attempted the application of different pesticides, yet sustainable solution was never achieved. For example, in Nigeria, some farmers have applied pesticides such as fipronil, aldrin, imidacloprid, chlorpyrifos, sulfluramid, and heptachlor to control the pests by dressing the yam setts and farmlands. The problems of inaccessibility, high costs, human health safety, and ecological effects of these pesticides limit their usage (UNEP 2000; Boonyatumanond et al. 2006; Sánchez-Bayo 2014). The need for a sustainable method of ameliorating this yam pest and to have increased yield became crucial due to higher food demand from the growing population. In other West African country such as Ghana, it was reported that traditional methods (wood ash, cow dung, and aqueous extract of plant residues "dawadawa") have been successfully used to control the yam pests (Asante et al. 2008). The records 
about such traditional applications are yet to be found in Nigeria. Therefore, the present study aimed at appraising a new biotrado-cultural approach of coping with the climate change by controlling the termites, improving the soil properties, and increasing yam production using aqueous extract of E. guineensis, $V$. amygdalina, and $C$. odorata. The study also compared the impacts of these plant materials on the soil, yam yield, and termites in relation to the result from the fipronil treatment. It is hypothesized that (i) $C$. odorata enriched the soil minerals and increased yam yield by reducing the effects from climate change and the termites; (ii) the attraction of E. guineensis sludge to termites makes it an intervening material that reduced the pests' attack on the yam tubers and consequently enhanced the soil organic carbon (Corg); and (iii) V. amygdalina and fipronil treatments can successfully control termites but they have high concentrations of trace elements which aggravate the impacts of climate change and exert negative effects on the soil and yam production. Within this context, the following questions were addressed: (a) What are the variations in the concentrations of soil chemical properties, under the different treatments applied, and how significant are these concentrations? (b) Which of the applied treatments and season increased soil essential minerals? (c) Does increase in Corg and rainfall increase yam production? (d) How sustainable is the fipronil application in relation to termites' control, soil fertility, and yam yield? (e) To what extent does the variability in climate influence the termites and their impacts on yam production?

\section{Materials and Methods}

\section{Study Area}

Ikpo is one of the oldest villages among the eight villages in Obibi community in Etche Local Government Area (ELGA) of Rivers State, Nigeria. The farmland is located within latitude $5^{\circ} 06^{\prime} 52.7^{\prime \prime} \mathrm{N}$ and longitude $7^{\circ} 11^{\prime} 59.4^{\prime \prime} \mathrm{E}$ (Fig. 1) with an area of about $52.2 \mathrm{~km}^{2}$ and a gentle sloping altitude ranging from $50 \mathrm{~m}$ to $100 \mathrm{~m}$ above sea level. The mean annual rainfall ranges from $100.4 \mathrm{~cm}$ to $241.7 \mathrm{~cm}$ and mean annual temperature ranging from $26.5{ }^{\circ} \mathrm{C}$ to $28.3{ }^{\circ} \mathrm{C}$ (SPDC 1998) (Fig. 2). The study was conducted from 2013 to 2016 under rainfed conditions. The mean monthly rainfall $(\mathrm{cm})$ and temperature $\left({ }^{\circ} \mathrm{C}\right)$ of the study site varied (Fig. 2) with 2013 and 2014 indicating normal rainfall years, 2015 revealing a dry year, and 2016 wet year. Though the study area has variations in rainfall that shows a bimodal rainfall distributional trend, yet no month without rainfall. Early-season rain begins in either late January or February and ends in July, and this is categorized as the early growing season. On the other hand, the late-season rain starts in August and ends in December (Nwaogu et al. 2017).

Geologically, the study site lies within Niger Delta Basin, and it is characterized by the Benin or coastal plain sand formation. The age of these formations ranges from Miocene to Eocene. 


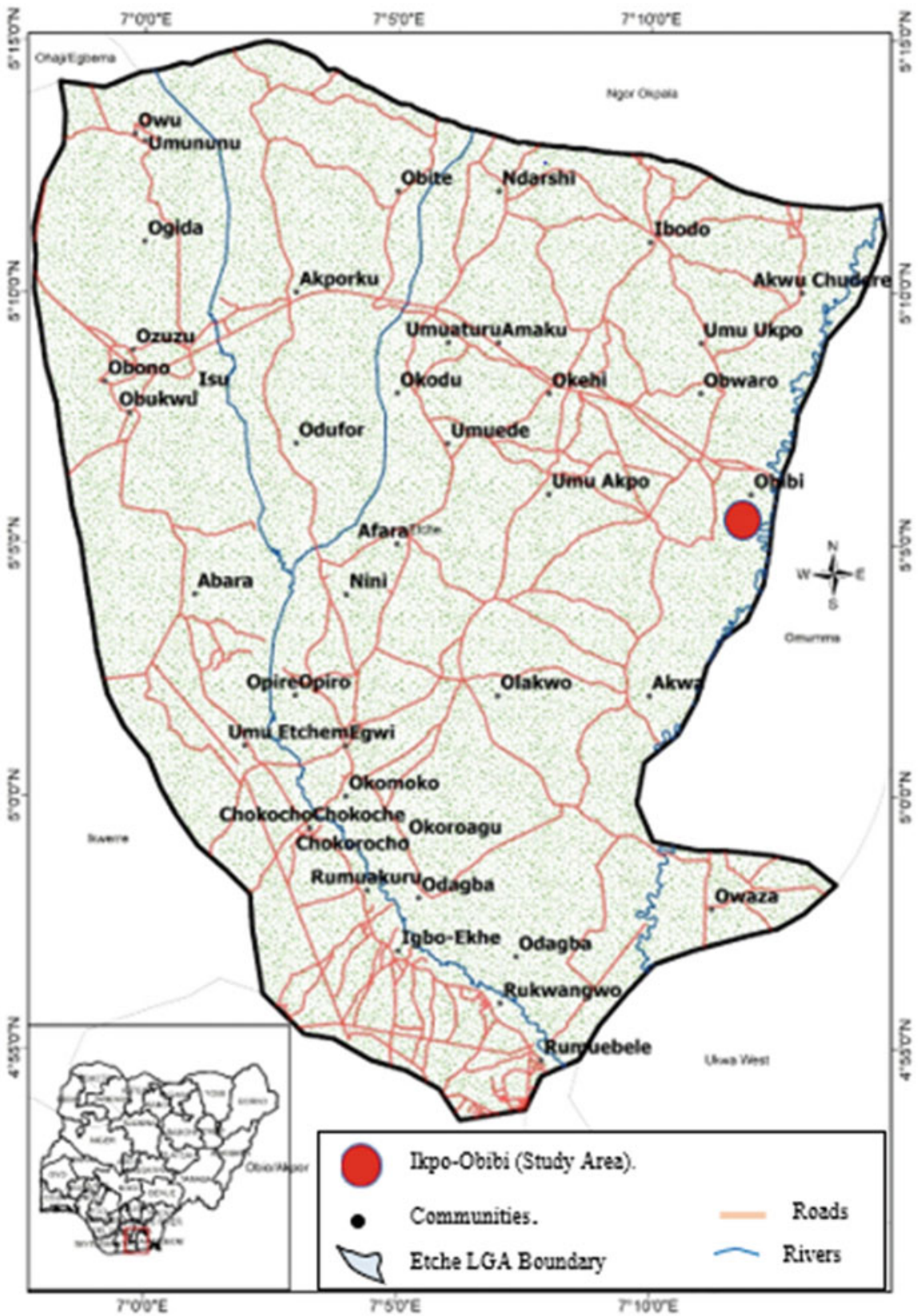

Fig. 1 The study area: Ikpo village in Obibi community, Etche LGA of Rivers State, Nigeria 


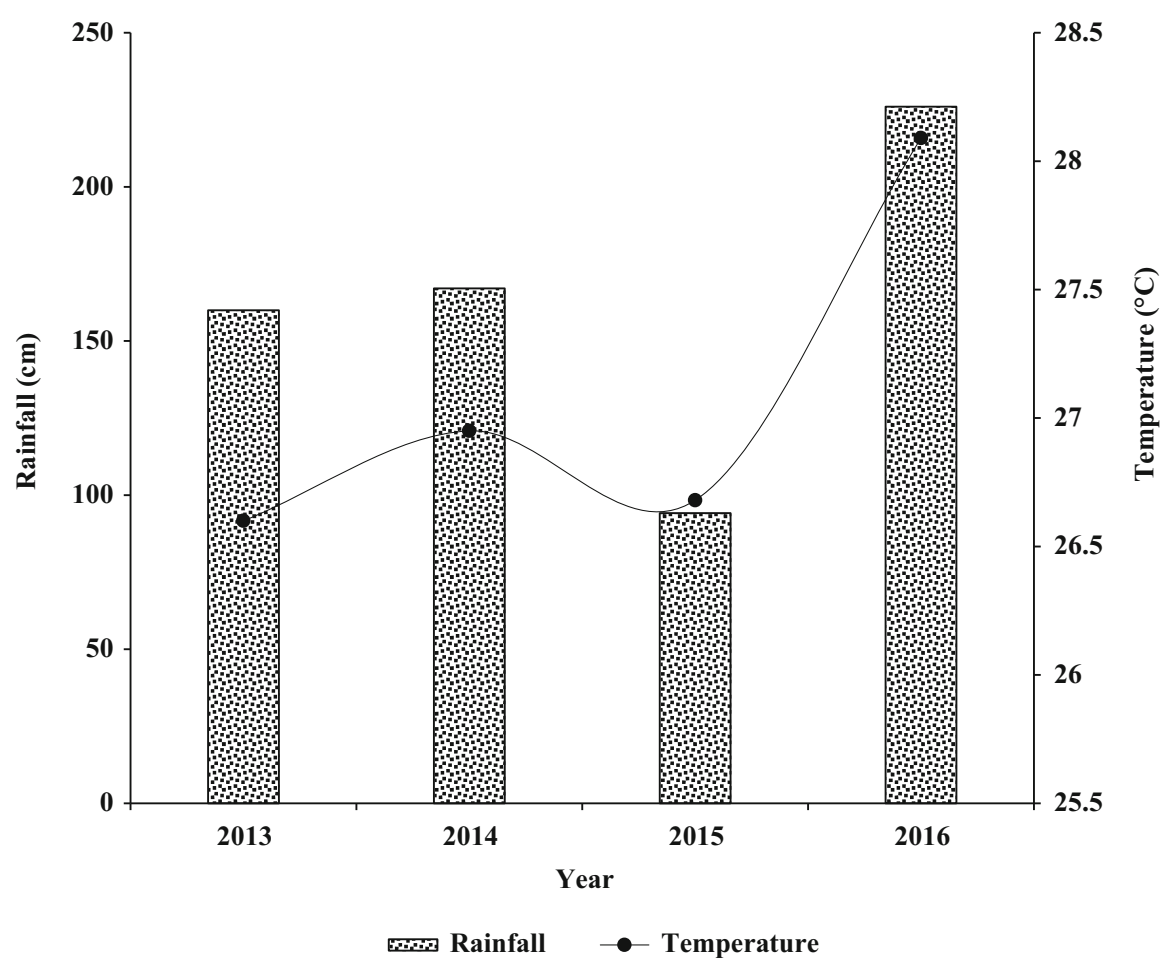

Fig. 2 Mean annual rainfall and temperature of the study area

The shallow parts of the formations are composed mainly of non-marine sand deposited in alluvial or upper coastal plain (Doust and Omatsola 1990). The soil composition of the study area consisted of fine alluvial content which is an extension of the rich sediments from the River Niger Delta alluvial soil. Presently, the heavy anthropogenic activities (e.g., mining, farming, grazing), pests, and environmental factors have influenced the soil properties (Table 1).

The study area is a typical rainforest region with traces of mangrove and freshwater swamp forests toward the south (Nwankwoala and Nwaogu 2009). There are bushes with trees and shrubs, as well as patches of grasslands dominated by elephant grasses where most farming activities are performed.

There are several termites' mounds which are between 2-7 m high and 2-5 $\mathrm{m}$ in diameter that cover the land space forming high termite mound density per hectare. Though the study site has for some years been dominated by termites, the activities of these pests to a large extent depend on climatic conditions. From the growing period to the maturity stage, the termites destroy the development of the crops planted at the site. This at most times leaves the rural farmers with little or nothing to be harvested. At planting and harvesting, five different species of termites were identified as the most common yam-destroying termites: Amitermes evuncifer, Macrotermes bellicosus, Microtermes obesi, Trinervitermes oeconomus, and Trinervitermes geminatus (Atu 1993; Loko et al. 2015). 
Table 1 Soil $(0-15 \mathrm{~cm}$ depth) chemical and physical properties in the study site prior to the experiment

\begin{tabular}{l|l}
\hline Soil property & Mean \pm standard error \\
\hline Corg $\left(\mathrm{mg} \mathrm{kg}^{-1}\right)$ & $5481 \pm 311$ \\
\hline $\mathrm{Ntot}\left(\mathrm{mg} \mathrm{kg}^{-1}\right)$ & $1197 \pm 95$ \\
\hline $\mathrm{P}\left(\mathrm{mg} \mathrm{kg}^{-1}\right)$ & $92.6 \pm 23.3$ \\
\hline $\mathrm{K}\left(\mathrm{mg} \mathrm{kg}^{-1}\right)$ & $471.1 \pm 37.7$ \\
\hline $\mathrm{Mg}\left(\mathrm{mg} \mathrm{kg}^{-1}\right)$ & $334.6 \pm 15.9$ \\
\hline $\mathrm{Ca}\left(\mathrm{mg} \mathrm{kg}^{-1}\right)$ & $421.4 \pm 33.4$ \\
\hline $\mathrm{Fe}\left(\mathrm{mg} \mathrm{kg}^{-1}\right)$ & $7.8 \pm 1.5$ \\
\hline $\mathrm{Mn}\left(\mathrm{mg} \mathrm{kg}^{-1}\right)$ & $6.1 \pm 0.9$ \\
\hline $\mathrm{Cu}\left(\mathrm{mg} \mathrm{kg}^{-1}\right)$ & $5.9 \pm 1.2$ \\
\hline $\mathrm{Zn}\left(\mathrm{mg} \mathrm{kg}^{-1}\right)$ & $8.8 \pm 1.1$ \\
\hline $\mathrm{Cr}\left(\mathrm{mg} \mathrm{kg}^{-1}\right)$ & $5.0 \pm 0.3$ \\
\hline $\mathrm{pH}$ & $6.1 \pm 0.5$ \\
\hline Sand $\left(\mathrm{g} \mathrm{kg}^{-1}\right)$ & $716 \pm 10.4$ \\
\hline Silt $\left(\mathrm{g} \mathrm{kg}^{-1}\right)$ & $118 \pm 6.1$ \\
\hline Clay $\left(\mathrm{g} \mathrm{kg}^{-1}\right)$ & $161 \pm 4.3$ \\
\hline Textural class & Sandy-loam \\
\hline Bulk density $\left(\mathrm{Mg} \mathrm{m}^{-3}\right)$ & $1.3 \pm 0.1$ \\
\hline
\end{tabular}

\section{Experimental Design, Yam Cultivation, and Treatments}

The study was conducted in a randomized block design (Fig. 3). The area covered $5,400 \mathrm{~m}^{2}$ with about $80 \%$ of the entire field being used for the yam cultivation and treatments, while the remaining percentage consisted of the borders around the entire treatment plots. Each plot consisted of $144 \mathrm{~m}^{2}(12 \mathrm{~m} \times 12 \mathrm{~m})$ and was separated by $4 \mathrm{~m}$ (column) and $2 \mathrm{~m}$ (row) buffer zones. Land preparation for the experiment took place in 2012, and the first phase of the experiment was performed in 4 years (2013-2016) characterized with differences in annual rainfall and temperature. For instance, 2013 and 2014 had a normal rainfall, 2015 was a dry year, and 2016 recorded excess rainfall.

The experimental design includes five blocks, five replicates, five different treatments (UM, unmanaged; VA, Vernonia amygdalina; CO, Chromolaena odorata; EG, Elaeis guineensis liquid sludge; FP, fipronil) (Fig. 3), and their chemical compositions (Table 2).

The land was cleared and the plants' litter removed. Yam planting heaps of 80 $100 \mathrm{~cm}$ high and $100-120 \mathrm{~cm}$ in diameter were prepared every year before the first rainfall of the year. After the first 2-3 rains of the year, yam setts were planted on the prepared heaps/mounds which were at the intervals of $15-20 \mathrm{~cm}$ with the cut face placed up (Fig. 4).

Based on the local tradition, the mounds were preferable to the ridges because they promoted easy staking and enhance the production of larger yam tubers when compared with ridges. The VA, $\mathrm{CO}$, and EG treatments were traditionally processed by crushing, soaking in water, and squeezing out the sludge which were stored in 0.7 liter plastics (Appendix Figs. 8, 9, 10, 11, and 12). These were preserved in a cool 


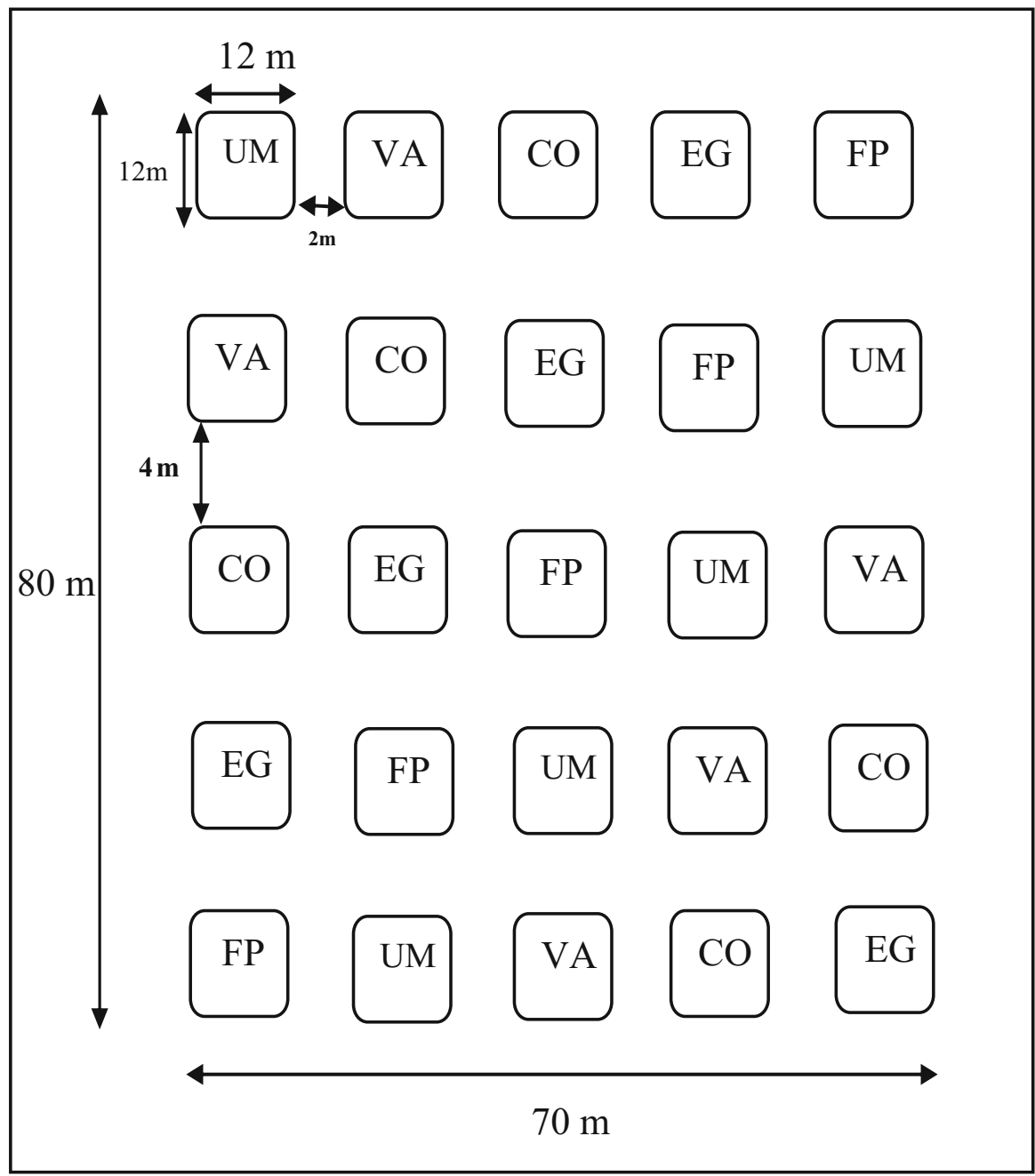

Fig. 3 Experimental design block for the study. Treatments were UM (unmanaged), VA (Vernonia amygdalina), CO (Chromolaena odorata), EG (Elaeis guineensis liquid sludge), FP (fipronil)

temperature to prevent fermentation before being applied to the yam heaps. On the other hand, the aqueous dilution of fipronil (Fipronil (120068-37-3); Alina Zhao, Ningbo Samreal Chemical Co., Ltd., China) was prepared as prescribed on the product label for termites' control. The prepared treatments were applied by dressing the yam setts. Between 0.2 and 0.3 litters of sludge (or aqueous) were dropped in and around every heap where the yam was planted. This was performed three times (in February/March, August, and November) for each growing season. By using hoes, manual weeding was performed three times (in late May, August, and November) for each growing season. Two stakes, each of $200-300 \mathrm{~cm}$ in height, 
Table 2 Mineral and trace element contents $\left(\mathrm{mg} \mathrm{L}^{-1}\right)$ of the organic materials used for the treatments (mean \pm standard error of the mean)

\begin{tabular}{l|l|l|l|l}
\hline & \multicolumn{3}{|l}{ Treatment material } & \\
\hline & & VA & CO & EG \\
\hline Minerals & $\mathrm{P}$ & $83.9 \pm 5.6$ & $116.1 \pm 23.5$ & $154.6 \pm 12.1$ \\
\hline & $\mathrm{K}$ & $52.1 \pm 7.3$ & $181.9 \pm 15.2$ & $271.2 \pm 25.6$ \\
\hline & $\mathrm{Mg}$ & $33.8 \pm 2.9$ & $104.6 \pm 27.7$ & $67.6 \pm 7.3$ \\
\hline & $\mathrm{Ca}$ & $76.4 \pm 11.1$ & $93.3 \pm 12.9$ & $48.7 \pm 2.5$ \\
\hline & $\mathrm{Fe}$ & $36.1 \pm 9.7$ & $22.8 \pm 8.1$ & $11.3 \pm 1.0$ \\
\hline & $\mathrm{Mn}$ & $3.3 \pm 0.4$ & $0.4 \pm 0.0$ & $0.3 \pm 0.0$ \\
\hline & $\mathrm{Cu}$ & $5.2 \pm 1.6$ & $0.7 \pm 0.1$ & $0.9 \pm 0.2$ \\
\hline & $\mathrm{Zn}$ & $2.4 \pm 0.7$ & $0.2 \pm 0.0$ & $0.8 \pm 0.3$ \\
\hline & $\mathrm{Cr}$ & $2.3 \pm 0.3$ & $0.1 \pm 0.0$ & $0.2 \pm 0.0$ \\
\hline & & & &
\end{tabular}
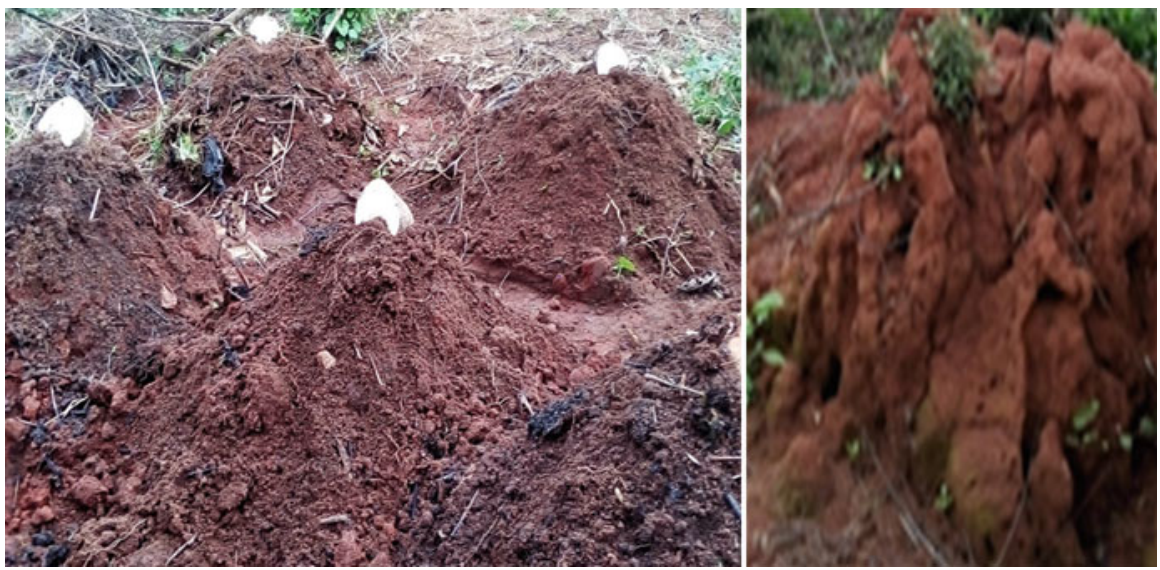

Fig. 4 Experiment site with yam soil heaps during planting and one of the termites' mounds

were used for staking the yam plants to vine over them - one stake for two plants and the other stake used for bracing the adjacent. Yam tuber harvesting was done in December each year following the local tradition.

\section{Soil Sampling and Chemical Properties Analyses}

In February/March and December, five soil sub-samples (0-15 cm soil depth) from individual treatment plot were randomly collected using a graduated auger. The soil samples were mixed and air-dried; visible pebbles, biomass residues, roots, and other organic debris were removed. Before taken to the laboratory for analysis, the samples were ground in a mortar to pass a $2 \mathrm{~mm}$ sieve. All measurements and analyses were performed within 30 days of sampling. The soil $\mathrm{pH}\left(\mathrm{H}_{2} \mathrm{O}\right)$ was determined by the method of McLean (1982). Organic carbon (Corg) was measured 
using the Walkley and Black wet oxidation method (Nelson and Sommers 1996). Total nitrogen (Ntot) was analyzed using micro-Kjeldahl method (Bremner and Mulvaney 1982). Available P, K, Ca, and Mg were extracted using Mehlich III solution (Mehlich 1984) with reagent and concentrations determined by introducing the inductively coupled plasma-optical emission spectrometry (ICP-OES: 720 Series, Agilent Technologies, USA). On the other hand, the concentrations of the trace elements $(\mathrm{Cu}, \mathrm{Mn}, \mathrm{Cr}, \mathrm{Fe}, \mathrm{Zn})$ were determined following the Clayton and Tiller (1979) method. The concentrations were further analyzed using ICP-OES analyzer. The mean of five sub-samples from each monitored treatment was used for the statistical analyses.

\section{Termites Sampling}

The number of termites per heap was collected three times per year: in February/ March (during planting), August (during the short break, that is, the August rainfall break), and December (during harvesting). These periods coincided with the low rainfall months which formed the peak season for the termites' activities (Loko et al. 2015). The termites were observed and counted using the Zoom Handheld Lighted Magnifier Glass (MagniPros 5.5", USA) by randomly selecting the yam heaps and excavating through to the soil profile where the yam tubers could be found. One-third of the heaps were sampled per plot.

\section{Yam Yields}

At physiological maturity, after 9-10 months (that is, in December), the yam tubers were harvested by randomly selecting the yam heaps and excavating through to the soil layers where the yam tubers could be found. One-third of the heaps were sampled per plot. The harvested tubers were washed using water. They were thereafter weighed, and result was recorded in yield per hectares.

\section{Statistical Analyses}

To test the effects of treatments on the soil chemical properties, yam yield, and number of termites, a one-way ANOVA was used. In addition, a repeated-measures ANOVA was applied to deduce the effect of year, treatment, and year $\mathrm{x}$ treatment interaction for number of termites, yam yields, soil minerals, and trace elements. The ANOVA was applied after the assumptions of normality were met. Regression analysis was used to test the relationship between yam tuber yield $\left(\mathrm{t} \mathrm{ha}^{-1}\right)$ and number of termites per yam soil heap. All analyses were conducted using the IBM SPSS Statistics Version 20 (IBM Corporation 2011) (www.ibm-spss-statistics. soft32.com) and the STATISTICA 13.0 software (StatSoft, Tulsa, OK, USA), while all data were expressed as means of five replicates. 
Furthermore, a multivariate analysis such as redundancy analysis (RDA) followed by a Monte Carlo permutation test with 999 permutations in the Canoco 5.0 software (Šmilauer and Lepš 2014) was used to measure the effect of the different treatments on soil chemical properties during the 4 years. Ordination diagram was produced by using the CanoDraw program software which prompted the presentation and visualization of the RDA results of the experiment.

\section{Results}

\section{Soil Chemical Properties}

The concentrations of all the monitored soil chemical properties were significant under the different treatments except for $\mathrm{Mn}$ and $\mathrm{Cu}$ (Table 3). Most of the measured minerals showed higher concentrations under the $\mathrm{CO}$ treatment when compared with VA, EG, UM, and FP treatments. On the other hand, VA and FP treatments had higher trace element concentrations and higher $\mathrm{pH}$ when compared with the other treatments. All the essential soil minerals were significantly affected by time and treatment, but not all were affected by the combination of both (i.e., time $\times$ treatment interaction) (Table 4).

No significant effect of treatment on soil chemical properties calculated by RDA was recorded in 2015 (Table 5). The variability of soil chemical properties explained by treatments subsequently increased from the initially $24 \%$ in 2013 to more than $25 \%$ in 2014 and more than $50 \%$ in 2016 . Variability explained by treatments was constantly above $20 \%$ between 2013 and 2016 .

The treatments were categorized into three different groups in relation to the concentrations of soil chemical properties as were revealed by the ordination diagram (Fig. 5). Based on the RDA analysis of the data collected during the 4 years, $\mathrm{CO}$ and EG treatments formed the first group, VA and FP treatments as the second group, and UM treatment as the third group. The relationships between individual soil element and treatment are visible from the ordination diagram (Fig. 5).

\section{Yam Tuber Yield and Termites}

The mean annual yam tuber yields under CO and EG treatments were significant, while UM, VA, and FP treatments never showed any significant differences during the study years (Fig. 6). Year 2015 had the lowest yam tuber yields under the different treatments, while 2013 had the highest.

The results from the total number of termites per yam heap showed that UM and EG treatments were significant at $P<0.05$, while records for $\mathrm{VA}, \mathrm{CO}$, and FP treatments revealed no statistical differences in the years (Fig. 7). Year 2015 had the highest number of termites per heap, whereas 2016 had the lowest. The relationships between yam tuber yield and number of termites per heap were negatively significant under the $\mathrm{CO}$ and $\mathrm{EG}$, while UM treatment $\left(\mathrm{R}^{2}=0.50 ; P=0.045\right)$ showed a marginal weak relationship (Table 6). 


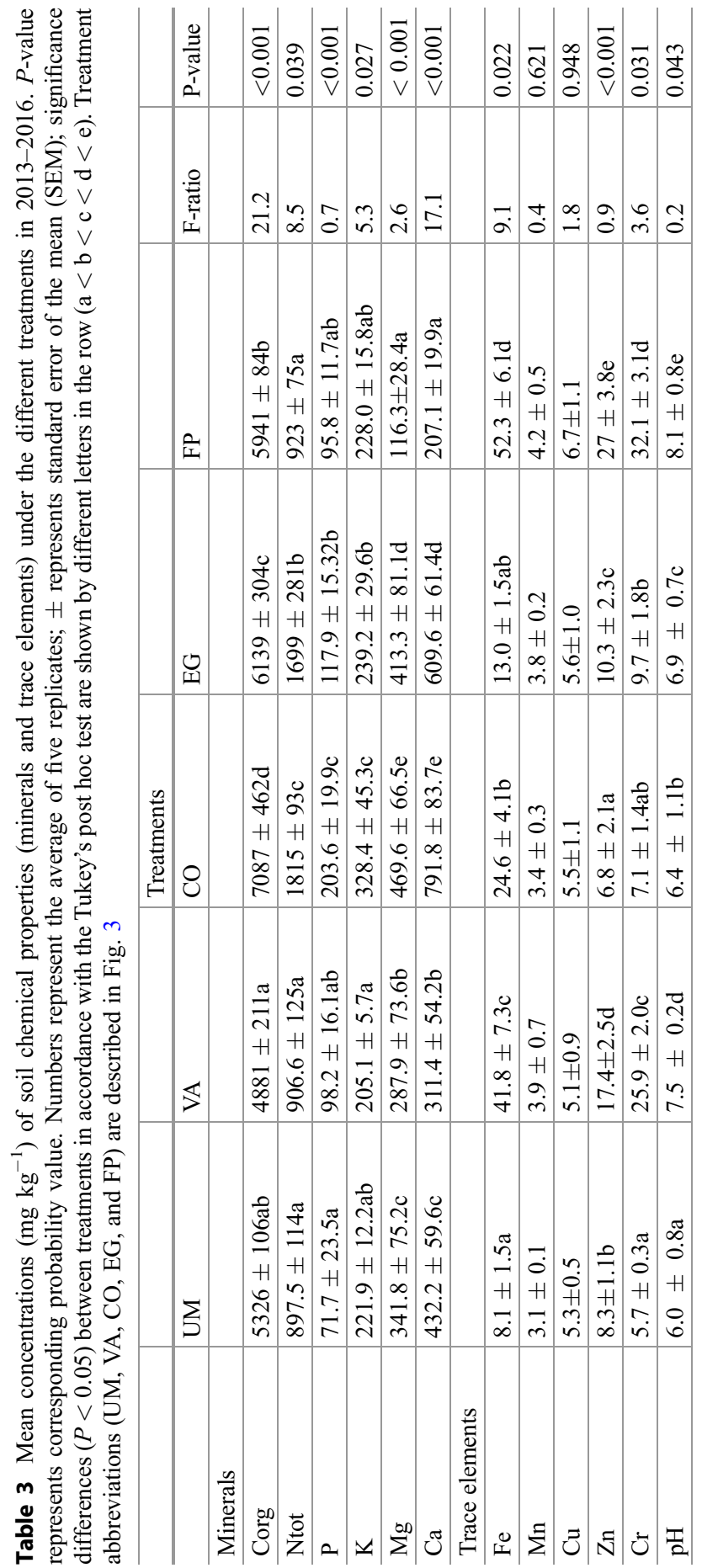


Table 4 Results of repeated-measures ANOVA (time, treatment, time $\times$ treatment) of soil chemical properties, number of termites, and yam yields. df, degree of freedom; F, value derived from F-statistics in repeated-measures ANOVA; and $P$, probability value

\begin{tabular}{|c|c|c|c|c|c|c|}
\hline & \multirow{3}{*}{$\begin{array}{l}\text { Time: } \mathrm{df}=4 \\
F \text {-ratio }\end{array}$} & \multirow[b]{3}{*}{$P$-value } & Effect & & & \\
\hline & & & \multicolumn{2}{|c|}{ Treatment: $\mathrm{df}=5$} & \multicolumn{2}{|c|}{$\begin{array}{l}\text { Time } \times \text { treatment: } \\
\mathrm{df}=20\end{array}$} \\
\hline & & & $F$-ratio & $P$-value & $F$-ratio & $P$-value \\
\hline \multicolumn{7}{|c|}{ Soil chemical properties } \\
\hline Corg & 23.5 & $*$ & 11.8 & $*$ & 3.1 & $*$ \\
\hline Ntot & 14.1 & $*$ & 24.3 & $*$ & 1.8 & $*$ \\
\hline $\mathrm{P}$ & 3.9 & $*$ & 5.9 & $*$ & 0.3 & ns \\
\hline K & 3.3 & $*$ & 17.7 & $*$ & 0.5 & ns \\
\hline $\mathrm{Mg}$ & 10.2 & $*$ & 6.8 & $*$ & 2.4 & $*$ \\
\hline $\mathrm{Ca}$ & 9.7 & $*$ & 18.3 & $*$ & 1.2 & $*$ \\
\hline $\mathrm{Fe}$ & 0.6 & ns & 35.1 & $*$ & 0.4 & ns \\
\hline $\mathrm{Mn}$ & 0.9 & ns & 1.8 & ns & 0.7 & ns \\
\hline $\mathrm{Cu}$ & 1.8 & ns & 0.7 & ns & 0.5 & ns \\
\hline $\mathrm{Zn}$ & 31.7 & $*$ & 11.2 & $*$ & 2.7 & $*$ \\
\hline $\mathrm{Cr}$ & 25.5 & $*$ & 57.1 & $*$ & 3.1 & $*$ \\
\hline $\mathrm{pH}$ & 14.1 & $*$ & 8.5 & $*$ & 0.5 & ns \\
\hline Number of termites & 10.6 & $*$ & 17.9 & $*$ & 0.9 & ns \\
\hline Yam yield & 37.3 & $*$ & 22.3 & $*$ & 1.2 & ns \\
\hline
\end{tabular}

Note: ns, not significant; ${ }^{*}$, significant at $P<0.05$

Table 5 Results of RDA analyses of soil chemical properties estimates performed separately for each year. \% explanatory variable, concentrations, variability explained by one (all) ordination axis (measures of explanatory power of the explanatory variables); $F$-ratio, $F$-statistics for the test of analysis; $P$-value, probability value obtained by the Monte Carlo permutation test. Tested hypothesis: there is any effect of treatment on soil chemical properties for each year. Applied treatments were described in Fig. 3

\begin{tabular}{l|l|l|l|l}
\hline Year & $\begin{array}{l}\text { Explanatory } \\
\text { variables }\end{array}$ & $\begin{array}{l}\text { \% explanatory var. } \\
\text { 1st axis (all axes) }\end{array}$ & $\begin{array}{l}F \text {-ratio } \\
\text { 1st axis (all axes) }\end{array}$ & $\begin{array}{l}P \text {-value } \\
\text { 1st axis (all axes) }\end{array}$ \\
\hline 2013 & UM, VA, CO, EG, FP & $11.8(23.9)$ & $2.4(1.1)$ & $<0.001(<0.001)$ \\
\hline 2014 & UM, VA, CO, EG, FP & $34.3(30.7)$ & $8.7(3.9)$ & $<0.001(<0.001)$ \\
\hline 2015 & UM, VA, CO, EG, FP & $23.6(21.3)$ & $12.5(3.6)$ & $<0.31(0.045)$ \\
\hline 2016 & UM, VA, CO, EG, FP & $45.2(47.8)$ & $11.2(3.8)$ & $<0.001(<0.001)$ \\
\hline
\end{tabular}

\section{Discussion}

\section{Soil Chemical Properties}

The chemical elements contained in the treatment materials and the prevailing climate substantially influenced the soil chemical properties and consequently exerted significant effects on the different treatments. For example, the 


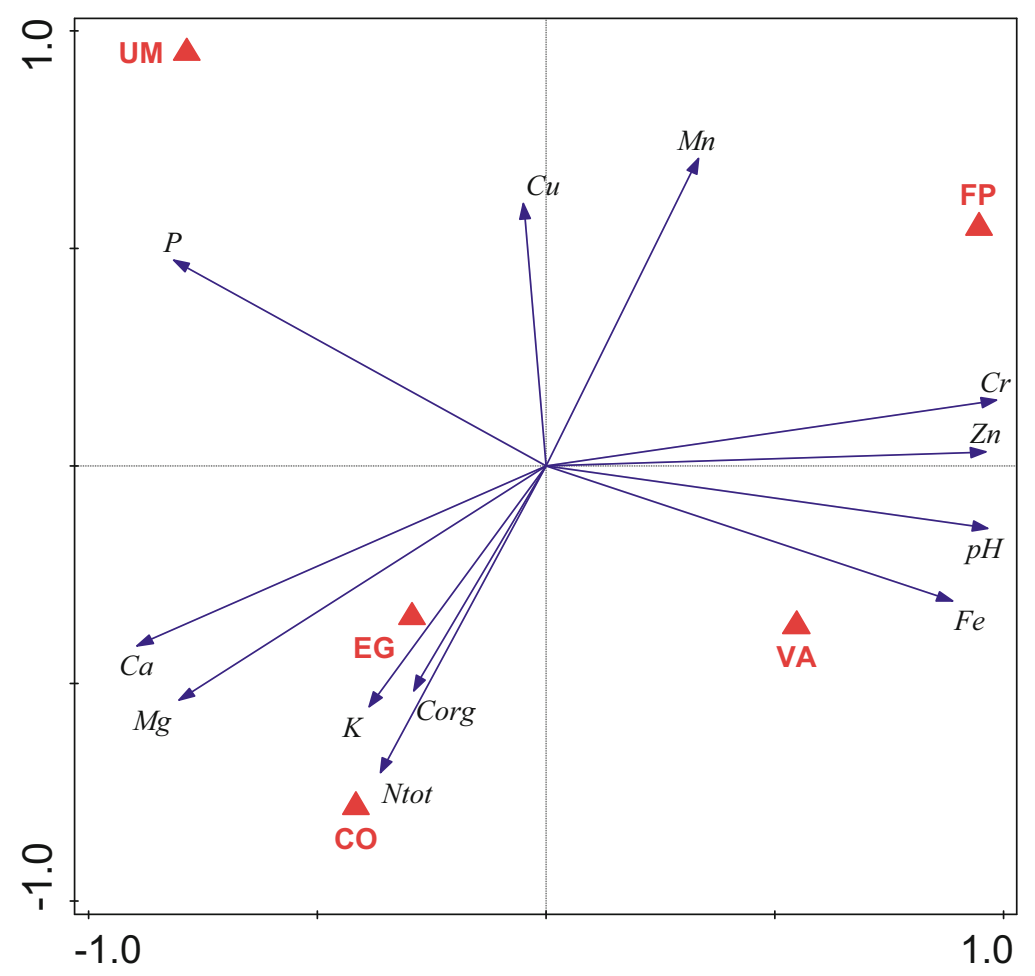

Fig. 5 Ordination diagram showing result of the RDA analysis of soil chemical properties data collected in 4 years (from 2013 to 2016) in different treatments. Treatment abbreviations are explained in Fig. 3

application of Vernonia amygdalina and fipronil (FP) elevated the concentrations of most trace elements in the soil, while Chromolaena odorata increased the contents of soil organic carbon and other minerals especially in the favorable climate years. Several studies have reported the effects of the exotic plants and organic residues of $V$. amygdalina, C. odorata, and Elaeis guineensis on the soil chemical properties and microbes (Kushwaha et al. 1981; Obatolu and Agboola 1993; Quansah et al. 2001; Peveling et al. 2003; Koutika et al. 2004; Callaway et al. 2004; Gbaruko and Friday 2007; Banful and Hauser 2011; Tondoh et al. 2013; Agbede et al. 2014; Gandahi and Hanafi 2014; Nurulita et al. 2014; Ngo-Mbogba et al. 2015; Ajayi et al. 2016; Dawson and Schrama 2016; Veldhuis et al. 2017).

It was discovered in the study that VA and FP treatments recorded relatively high soil $\mathrm{pH}$, and this might be attributed to the high concentrations of the trace elements. This finding was consistent with other studies which have revealed that the elevation of heavy metals in most agricultural soils often leads to soil alkalinity (Nederlof et al. 1993; Lenart and Wolny-Koładka 2013; Almaroai et al. 2014) and V. amygdalina like Baphia nitida accumulates high heavy metals in the region (Ogbonna et al. 2013). On 
$\square 2013 \square 2014 \square 2015 \square 2016$

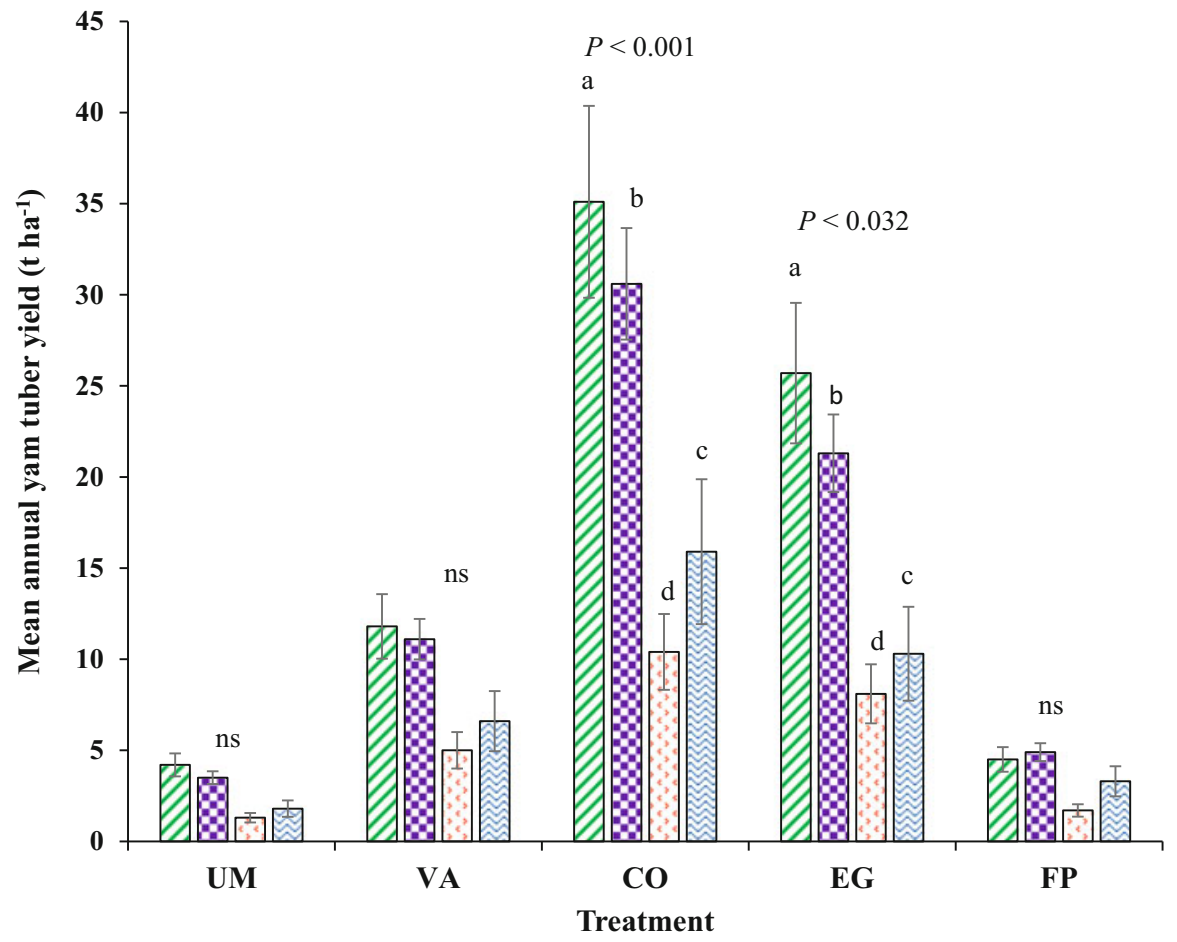

Fig. 6 Mean annual yam tuber yield $\left(\mathrm{t} \mathrm{ha}^{-1}\right)$. Error bars represent standard error of the mean (SEM). $P$-value represents corresponding probability value. $n s$ indicates that the results of ANOVA analyses were not significant. Significance differences $(P<0.05)$ between treatments in accordance with the Tukey's post hoc test are shown by lowercase letters $(\mathrm{a}>\mathrm{b}>\mathrm{c}>\mathrm{d})$. Treatment abbreviations were explained in Fig. 3

the contrary, other authors have reported high concentrations of exchangeable $\mathrm{Cd}$ and $\mathrm{Zn}$ in agricultural soils because of decrease in $\mathrm{pH}$ (Sumi et al. 2014).

Although $C$. odorata has been established to be a threat to the soil minerals by some authors (Muniappan et al. 2005), in contrast, several studies in West Africa have positive records about C. odorata (Obatolu and Agboola 1993; Goyal et al. 1999; Quansah et al. 2001; Tondoh et al. 2013; Agbede et al. 2014). In agreement with our study, CO treatment revealed increased concentrations of Corg, Ntot, $\mathrm{K}$, and $\mathrm{Ca}$ especially in the optimal precipitation years. This might be explained by the deep rooting system of $C$. odorata that mobilizes soil mineral nutrients which are turned into organic and plant-available nutrients in conducive climate (Kushwaha et al. 1981; Tondoh et al. 2013). Other possible reasons for high contents of minerals in the C. odorata soil could be due to high contents of leaf biomass and earthworms (Tian et al. 2000; Kone et al. 2012), fast decomposing rate of C. odorata (Roder et al. 1995), and the elevated activities of the soil microbes (Mboukou-Kimbasta et al. 2007; Banful and Hauser 2011; Ngo-Mbogba et al. 2015; Dawson and Schrama 2016). 


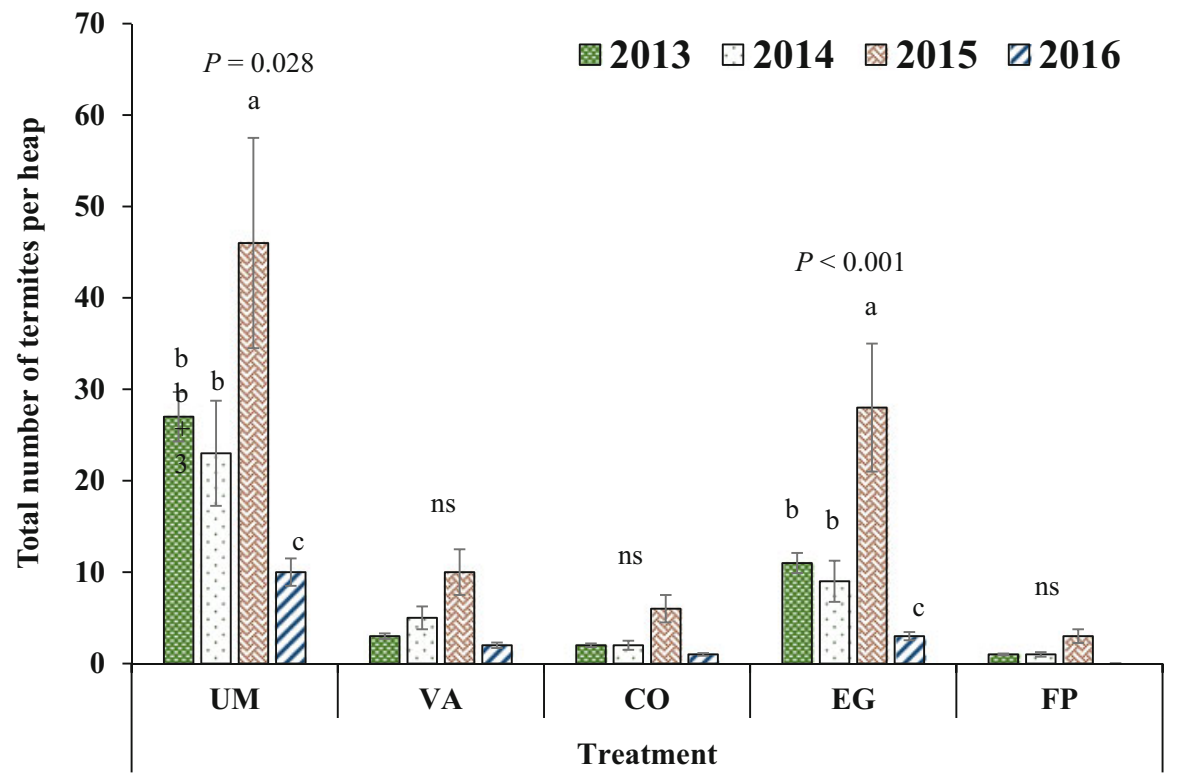

Fig. 7 Total number of termites (Isoptera) per yam soil heap. Error bars represent standard error of the mean (SEM). $P$-value represents corresponding probability value. $n s$ indicates that the results of ANOVA analyses were not significant. Significance differences $(P<0.05)$ between treatments in accordance with the Tukey's post hoc test are shown by lowercase letters $(a>b>c>d)$. Treatment abbreviations were explained in Fig. 3

Table 6 Relationships between yam tuber yield $\left(\mathrm{kg} \mathrm{heap}^{-1}\right)$ and number of termites per yam heap for the years under the different treatments

\begin{tabular}{l|l|r|r}
\hline Treatment & Equation & $\mathrm{R}^{2}$ & P-value \\
\hline UM & $\mathrm{Y}=-0.0059 \mathrm{X}+17.593$ & 0.50 & 0.045 \\
\hline VA & $\mathrm{Y}=-0.014 \mathrm{X}+18.824$ & 0.21 & 0.079 \\
\hline CO & $\mathrm{Y}=-0.2456 \mathrm{X}+35.04$ & -0.87 & $<0.001$ \\
\hline EG & $\mathrm{Y}=-0.064 \mathrm{X}+29.618$ & -0.75 & 0.012 \\
\hline FP & $\mathrm{Y}=-0.0128 \mathrm{X}+15.53$ & 0.24 & 0.063 \\
\hline
\end{tabular}

On the other hand, E. guineensis (EG) treatment had elevated soil organic carbon and total nitrogen in our study. This result was consistent with many studies which reported that the oil palm residues promote the scavenging activities of ants which enrich the soil minerals (Frouz et al. 1997; Gandahi and Hanafi 2014; Nurulita et al. 2014; Gray et al. 2015).

No significant effect of treatment on the soil chemical properties was recorded in 2015 as shown by the RDA analysis. The low amount of rainfall recorded in 2015 contributed to the insignificant role of treatments on the soil because the elements from the treatments required enough soil moisture to show reasonable influence on the soil chemistry (Fernelius et al. 2017). 


\section{Yam Tuber Yield and Termites}

The highest yam tuber yields were found in the $\mathrm{CO}$ treatment. This might probably be explained by high Corg, Ntot, $\mathrm{P}, \mathrm{K}, \mathrm{Ca}$, and $\mathrm{Mg}$ in the soil under the $\mathrm{CO}$ treatment which consequently increased the crop yield (Obatolu and Agboola 1993; Quansah et al. 2001; Tondoh et al. 2013; Agbede et al. 2014). Similarly, 2013 and 2014 had the highest yam tuber yields across the different treatments. This was attributed to the optimum rainfall in 2013 and 2014 which did not only favor the activities of the microbial organisms but also helped to decrease the number of the termites' attack on the yam tubers. Though the oil palm (EG) liquid sludge attracted more termites in the soil yet, the EG treatment had higher yam tuber yields than UM and VA treatments. This could be because the termites fed more on the oil palm sludge instead of the yam tubers. Besides, the termites' activities improved the soil minerals (Oviasogie and Aghimien 2003; Muhrizal et al. 2006; Guo et al. 2007; Wu et al. 2009).

The total number of termites per yam heap were significant under UM and EG treatments. This was because of the suitability of the unmanaged and E. guineensis (EG) treatments which promoted the termites' activities when compared with the VA, CO, and FP treatments that either constrained or killed the ants (Peveling et al. 2003). Though without high yam yields, fipronil application was the easiest method to eradicate the termites from either destroying the yam tubers or carrying out any activities in the yam farmland. But the risk of fipronil on the soil, environment, and human health has been reported by many authors (Keefer and Gold 2014; SánchezBayo 2014; Lopez-Antia et al. 2016).

\section{Limitations of the Study}

Some of the limitations for the study are:

(i) Poor access roads and footpaths to the farm sites where the studies are conducted

(ii) Destruction of some established experiments by mammals such as rabbits (Oryctolagus cuniculus), rats (Rattus), grasscutters (Thryonomys swinderianus), antelopes (Bovidae), and others

(iii) Ability to convince the rural farmers to give their farmlands for such research because some of the farmers are afraid that their land might be taken by the government or the research institutes

(iv) Inadequate fund to perform intensive studies: labor, field, laboratory and statistical analyses, and publications

(v) Dearth of literature on the topic in Nigeria and lack of robust data on the climate and other variables 


\section{Conclusion}

Climate change with its variability was found as a factor which has important influence on yam tuber production because (i) the termite colonies increased when there is low rainfall, (ii) the damage caused by the pests exacerbates during dry season than in wet season, and (iii) optimal rainfall enhances soil moisture and promotes the soil microbial activities and decomposition of organic matter which in turn elevates the soil fertility. Chromolaena odorata (CO) treatment has been found to be the best single option in managing the termites' infested farmland to increase yam yield. On the other hand, integrating $\mathrm{CO}$ and EG treatment is recommended as this might produce higher yield. Though the termites (pests) were successfully reduced under the VA and FP treatments, this reduction was not commensurate with the yam tuber yield. The high content of the trace elements in the VA and FP treatments was attributed to the reason for declined yields because the fipronil is a good soil-binding substance which limits organic decomposition and nutrient cycling. It is also important to state here that a 4-year study is a short term to conclude that $C$. odorata and $E$. guineensis sludge are sustainable for reducing the yam pests (termites) and their harmful activities.

Since climate change is expected to continue locally and globally, this will have further influence on the distribution and intensification of termites which in turn affects agricultural resources. There is crucial need for the effectiveness of termite management strategies which include integrated pest control methods. Furthermore, as most of the termites are soil inhabitants, soil degradation and low rainfall are the main factors promoting their distribution and forage behavior in both tropical and subtropical ecosystems. Thus, there are high chances for aggravated economic devastation of termites' outbreaks in the region due to climate change. Therefore, the experiment needs to be extended to other locations in the study region. It also requires an intensive and long-term investigation in order to thoroughly understand (i) the influence of climate change on the termites' outbreak, (ii) the extent of termite damage to the crops, (iii) the impacts of climate change and variability on yam yields, (iii) the agricultural and economic benefits of the applied treatments, and (iv) the ecological and human health safety of the treatments.

Acknowledgements The support from the Department of Forest Protection and Entomology, Faculty of Forestry and Wood Sciences, Czech University of Life Sciences, Czech Republic, and the grants "EVA4.0" No. CZ.02.1.01/0.0/0.0/16_019/0000803 from the EVA 4.0 project are appreciated.

\section{Appendix}

See Figs. 8, 9, 10, 11, and 12 . 
Fig. 8 Specimen of Vernonia amygdalina (VA) used for the experiment

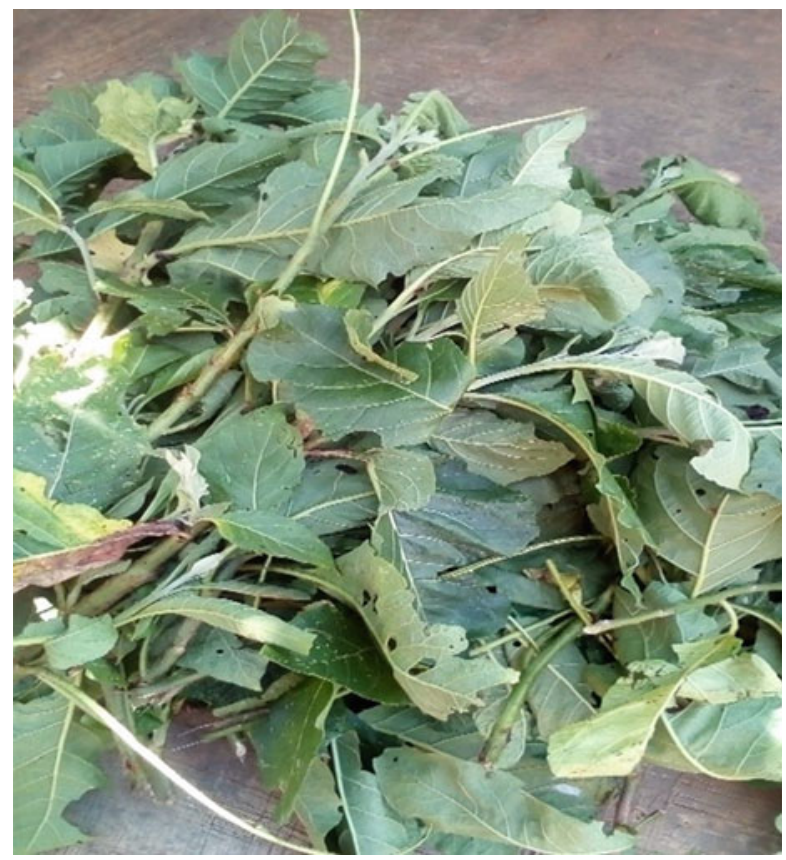

Fig. 9 Specimen of

Chromolaena odorata (CO) used for the experiment

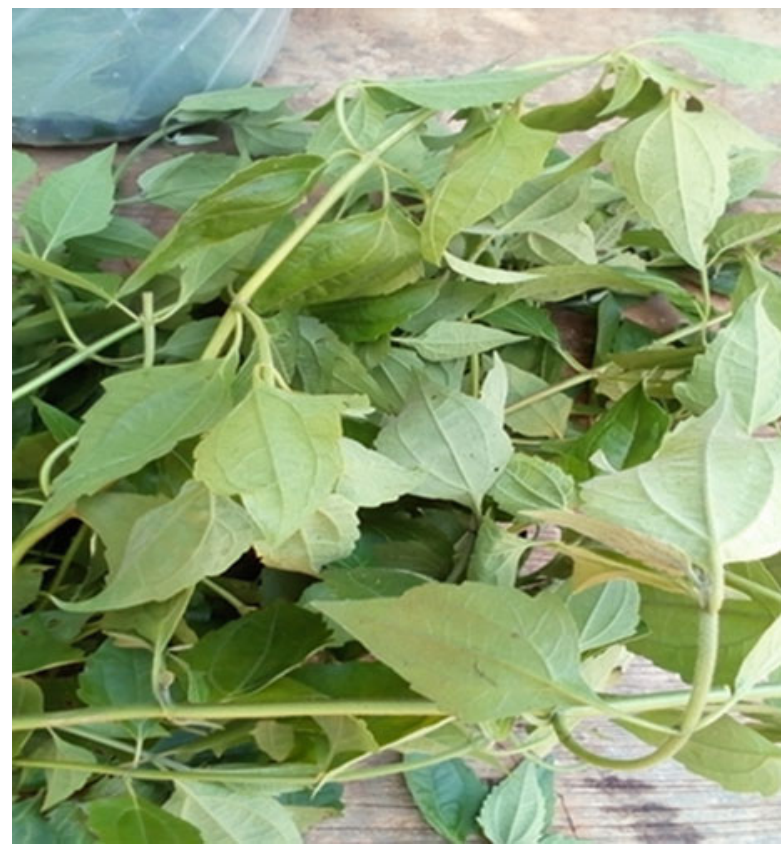


Fig. 10 Specimen of Elaeis guineensis (EG) and its liquid sludge used for the experiment

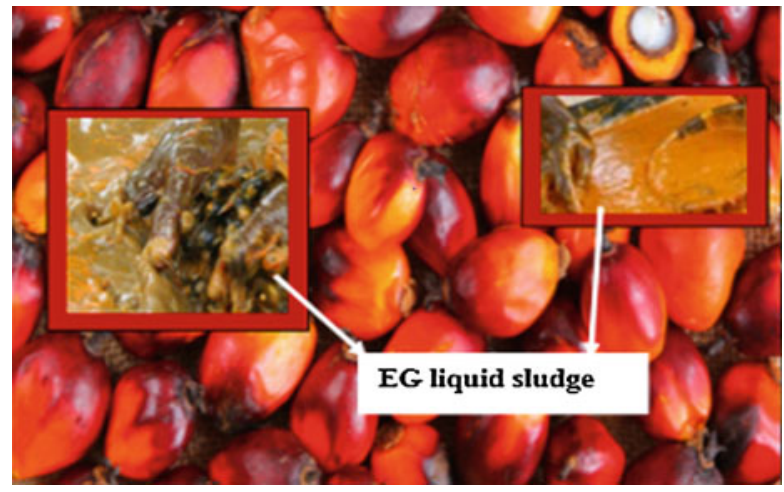

Fig. 11 Processing of the liquid/sludge of Vernonia amygdalina (VA), Chromolaena odorata (CO), Elaeis guineensis (EG)

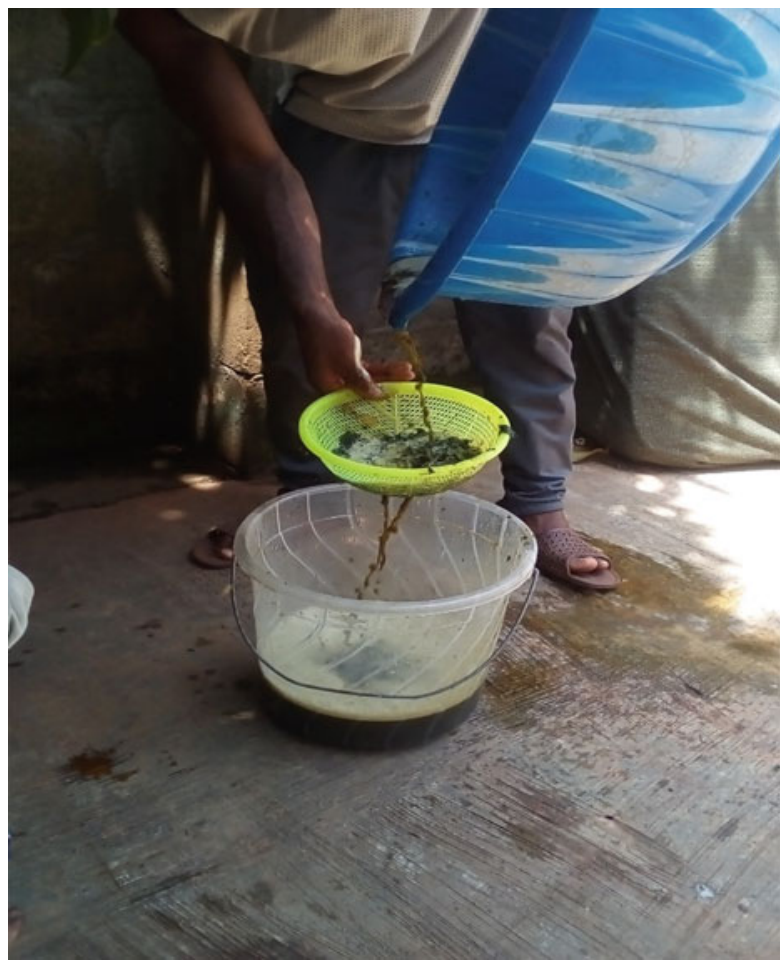


Fig. 12 Stored liquid/sludge of Vernonia amygdalina, Chromolaena odorata, Elaeis guineensis before they were applied in the experiment

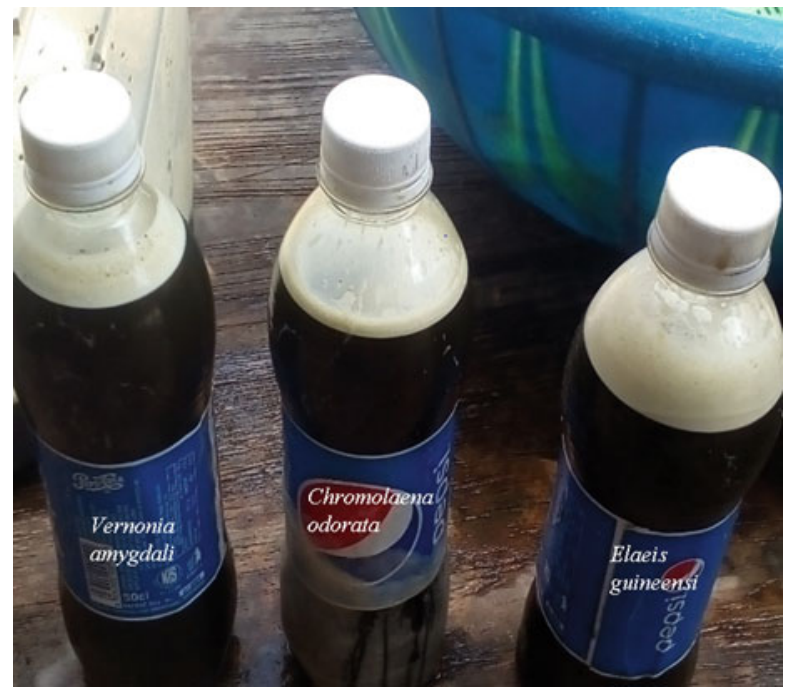

\section{References}

Agbede TM, Adekiya AO, Ogeh JS (2014) Response of soil properties and yam yield to Chromolaena odorata (Asteraceae) and Tithonia diversifolia (Asteraceae) mulches. Arch Agron soil sci 60:209-224

Ahmed BM, French JRJ (2008) An overview of termite control methods in Australia and their link to aspects of termite biology and ecology. Pak. Entomol 30:1-18

Ahmed MB, Nkunika POY, Sileshi GW, French JRJ, Nyeko P, Jain S (2011) Potential impact of climate change on termite distribution in Africa. Br J Environ Climate Chang 1(4):172-189

Ajayi FT, Omotoso SO, Odejide JO (2016) Evaluation of fodder plants (Ficus polita, Azadirachta indica and Vernonia amygdalina) for their phytochemical and antibacterial properties. Cog. Food Agric 2(1):1211466

Almaroai YA, Vithanage M, Rajapaksha AU et al (2014) Natural and synthesized iron-rich amendments for As and $\mathrm{Pb}$ immobilization in agricultural soil. Chem Ecol 30(3):267-279

Asante SK, Mensah GWK, Wahaga E (2008) Farmers' knowledge and perceptions of insect pests of yam (Dioscorea spp.) and their indigenous control practices in northern Ghana. Ghana J Agric Sci 40(2): 185-192

Atu UG (1993) Cultural practices for the control of termite (Isoptera) damage to yams and cassava in south-eastern Nigeria. Intern J Pest Manag 39:462-466

Banful B, Hauser S (2011) Changes in soil properties and nematode population status under planted and natural fallows in land use systems of southern Cameroon. Agrofor Syst 82:263-273

Beaudrot L, Du Y, Rahman Kassim A, Rejmanek M, Harrison RD (2011) Do epigeal termite mounds increase the diversity of plant habitats in a tropical rain forest in peninsular Malaysia? PLoS ONE 6(5):e19777

Belyaeva NV, Tiunov AV (2010) Termites (Isoptera) in forest ecosystems of Cat Tien national park (Southern Vietnam). Biol Bullet 37:374-381

Bignell DE, Eggleton P (2000) Termites in ecosystems. In: Abe T, Bignell DE, Higashi M (eds) Termites: evolution, sociality, symbioses, ecology. Kluwer Academic Publications, Dordrecht, pp 363-387 
Boko MI, Nyong NA, Vogel C, Githeko A, Medany M, Osman-Elasha B, Tabo R, Yanda P (2007) Africa climate change 2007: impacts, adaptation and vulnerability. Contribution of Working Group II to the fourth assessment report of the Intergovernmental Panel on Climate Change, Parry ML, Canziani OF, Palutikof JP, van der Linden PJ, Hanson CE (eds). Cambridge University Press, Cambridge UK, pp 433-467

Boonyatumanond R, Tabucanon MS, Thongklieng S, Boonchlaermkit S (2006) Persistent of organochlorine pesticides in the green Lip Mussel (Perna Viridis) from marine Estuaries in Thailand. Chem Ecol 17(1):31-39

Bremner JS, Mulvaney CS (1982) Nitrogen-total. In: Page AL (ed) Methods of soil analysis no. 9, Part 2, Chemical and microbiological properties. American Society of Agronomy, Madison

Buczkowski G, Bertelsmeier C (2017) Invasive termites in a changing climate: a global perspective. Ecol Evol 7:974-985

Callaway RM, Thelen GC, Rodriguez A, Holben WE (2004) Soil biota and exotic plant invasion. Nature 427:731-733

Christensen JH, Hewitson B, Busuioc A, Chen A, Gao X, Held I, Jones R, et al (2007) Regional climate projections. Climate change 2007: the physical science basis. Contribution of Working Group I to the Fourth Assessment Report of the Intergovernmental Panel on Climate Change, Solomon S, Qin D, Manning M, Chen Z, Marquis M, Averyt KB, Tignor M, Miller HL, Eds., Cambridge University Press, Cambridge, pp 847-940

Clayton PM, Tiller KG (1979) A chemical method for the determination of heavy metal content of soils in environmental studies: CSIRO, Australia Melbourne Division. Soil Technol 41:1-7

Consultative Group on International Agricultural Research (CGIAR) (2004) Research and impact: area of research: yam. C:IUserluser|Documents|Yam-CGIAR Research \& Impact Areas of Research Yam.mh

Dawson W, Schrama M (2016) Identifying the role of soil microbes in plant invasions. J Ecol 104:1211-1218

Devendra G, Ayo-Odongo J, Kit V, et al (1998) A participatory systems analysis of the termite situation in West Wollega, Oromiya region, Ethiopia. Working document series 68: ICRA/EARO/OADB (Oromia Agricultural Development Bureau), p 168

Doust H, Omatsola E (1990) Niger delta. In: Edwards JD, Santogrossi I (eds) Divergent and passive margin basins. AAPG Memoir, vol 48: Tulsa, American Association of Petroleum Geologists, Tulsa, pp 201-238

Eggleton P, Bignell DE, Hauser S, Dibog L, Norgrove L, Madong B (2002) Termite diversity across an anthropological gradient in the humid forest zone of West Africa. Agric Ecosyst Environ 90:189-202

Fernelius KJ, Madsena MD, Hopkins GB et al (2017) Post-fire interactions between soil water repellency, soil fertility and plant growth in soil collected from a burned piñon-juniper woodland. J Arid Environ 144:98-109

Frouz J, Santruckova H, Kalcik J (1997) The effect of wood ants (Formica polyctena Foerst.) on the transformation of phosphorus in a spruce plantation. Pedobiologia 41:437-447

Gandahi AW, Hanafi MM (2014) Bio-composting oil palm waste for improvement of soil fertility. Part of the Sustainable development and biodiversity book series (SDEB). Composting Sustain Agric 3:209-243

Gbaruko BC, Friday OV (2007) Bioaccumulation of heavy metals in some fauna and flora. Intern J Environ Sci Technol 4:197-202

Goyal S, Chander K, Mundra MC, Kappor KK (1999) Influence of inorganic fertilizers and organic amendments on soil organic matter and soil microbial properties under tropical conditions. Biol Fert Soil 29:196-200

Gray CL, Lewis OT, Chung AYC et al (2015) Riparian reserves within oil palm plantations conserve logged forest leaf litter ant communities and maintain associated scavenging rates. J Appl Ecol 52:31-40

Guo TR, Zhang GP, Zhang YH (2007) Physiological changes in barley plants under combined toxicity of aluminum, copper and cadmium. Colloids Surf B Biointerfaces 57:182-188

Harrington R, Stork NE (eds) (1995) Insects in a changing environment. Academic, London 
IBM Corporation (2011) IBM SPSS statistics for windows, version 20.0. Armonk: IBM Corporation. www.ibm-spss-statistics.soft32.com

Jones JA (1990) Termites, soil fertility and carbon cycling in dry tropical Africa: a hypothesis. J Trop Ecol 6:291-305

Keefer CT, Gold RE (2014) Recovery from leachate and soil samples of fipronil at termiticide concentration. Southwestern Entomol 39:705-716

Kemp PB (1955) The termites of North-Eastern Tanaganyika (Tanzania): their distribution and biology. Bull Entomol Res 46:113-135

Kone AW, Edoukou EF, Gonnety JT et al (2012) Can the shrub Chromolaena odorata (Asteraceae) be considered as improving soil biology and plant nutrient availability? Agrofor Syst $85: 233-245$

Koutika LS, Hauser S, Meuteum K et al (2004) Comparative study of soil properties under Chromolaena odorata, Pueraria phaseoloides and Calliandra calothyrsus. Plant Soil 266:315-323

Kurukulasuriya P, Mendelsohn R, Hassan R, Benhin J, Deressa T, Diop M, Dinar A et al (2006) Will African agriculture survive climate change? World Bank Econ Rev 20:367-388

Kushwaha SPS, Ramakrishnan PS, Tripathi RS (1981) Population dynamics of Eupatorium odoratum in successional environments following slash and burn agriculture. J Appl Ecol 18:529-535

Lenart A, Wolny-Koładka K (2013) The effect of heavy metal concentration and soil $\mathrm{pH}$ on the abundance of selected microbial groups within ArcelorMittal Poland Steelworks in Cracow. Bull Environ Contam Toxicol 90:85-90

Logan JWM, Cowie RW, Wood TG (1990) Termite (Isoptera) control in agriculture and forestry by nonchemical methods: a review. Bull Entomol Res 80:309-330

Loko YL, Agre P, Orobiyi A et al (2015) Farmers' knowledge and perceptions of termites as pests of yam (Dioscorea spp.) in Central Benin. Intern J Pest Manag 62(1):75-84

Lopez-Antia A, Feliu J, Camarero PR et al (2016) Risk assessment of pesticide seed treatment for farmland birds using refined field data. J Appl Ecol 53:1373-1381

Lovett JC, Midgley GF, Barnard P (2005) Climate change in Africa. Afr J Ecol 43:167-169

Mboukou-Kimbasta I, Bernhard-Reversat F, Loumeto JN et al (2007) Understorey vegetation, soil structure and soil invertebrates in Congolensis Eucalypt plantations, with special reference to the invasive plant Chromolaena odorata and earthworm populations. Eur J Soil Biol 47:48-56

McLean EO (1982) Soil pH and lime requirements. In: Page AL (ed) Methods of soil analysis. Part 2. Chemical and microbiological properties, 2nd edn. Agronomy series, 9. ASA, SSSA, Madison

Mehlich A (1984) Mehlich III soil test extractant: a modification of Mehlich 2 extractant. Commun Soil Sci Plant Anal 15:1409-1416

Muhrizal S, Shamshuddin J, Fauziah I et al (2006) Changes in iron-poor acid sulphate soil upon submergence. Geoderm 131:110-122

Muniappan R, Reddy GVP, Lai PY (2005) Distribution and biological control of Chromolaena odorata. In: Inderjit $\mathrm{S}$ (ed) Invasive plants: ecological and agricultural aspects. Birkhauser Verlag AG, Basel, pp 223-233

Nederlof MM, Van Riemsdijk WH, De Haan FAM (1993) Effect of pH on the bioavailability of metals in soils. In: Eijsackers HJP, Hamers T (eds) Integrated soil and sediment research: a basis for proper protection. Springer, Kluwer Academic Publishers, pp 215-219

Nelson DW, Sommers LE (1996) Total carbon, organic carbon and organic matter. In: Sparks DL (ed) Methods of soil analysis. Part 3, 2nd edn. SSSA book series no. 5. ASA and SSSA, Madison, pp 961-1010

Ngo-Mbogba M, Yemefack M, Nyeck B (2015) Assessing soil quality under different land cover types within shifting agriculture in South Cameroon. Soil Tillage Res 150:124-131

Nkunika POY (1998) Termite survey, identification, damage and control in southern province. Land Management and Conservation Farming, Soil Conservation and Agro forestry Extension Report, Lusaka, Zambia

Nurulita Y, Adetutu E, Kadali K et al (2014) The assessment of the impact of oil palm and rubber plantations on the biotic and abiotic properties of tropical peat swamp soil in Indonesia. Int J Agric Sustain 13(2):150-166 
Nwankwoala HO, Nwaogu C (2009) Utilizing the tool of GIS in oil spill management-a case study of Etche LGA, Rivers State, Nigeria. Glob J Environ Sci 8:19-29

Nwaogu C, Ogbuagu HD, Abrakasa S et al (2017) Assessment of the impacts of municipal solid waste dumps on soils and plants. Chem Ecol 33(7):589-606

Obatolu CR, Agboola AA (1993) The potential of Siam weed (Chromolaena odorata) as a source of organic matter for soils in humid tropics. In: Mulongoy M, Merckx R (eds) Soil organic matter dynamics and sustainability of tropical agriculture. Wiley-Sayce Co, New York, pp 89-99

Ogbonna PC, Odukaesieme C, Teixeira da Silva JA (2013) Distribution of heavy metals in soil and accumulation in plants at an agricultural area of Umudike, Nigeria. Chem Ecol 29(7):595-603

Olajumoke OL, Agiang MA, Mbeh E (2012) Proximate and anti-nutrient composition of white Guinea yam (Dioscorea rotundata) diets consumed in Ibarapa, South West region of Nigeria. J Nat Prod Plant Resour 2:256-260

Olorede KO, Alabi MA (2013) Economic analysis and modelling of effects of NPK fertilizer levels on yield of yam. Math Theory Model 3:108-118

Osunde ZD, Orhevba BA (2009) Effects of storage conditions and storage period on nutritional and other qualities of stored yam (Dioscorea spp.) tubers. African Journal of Food, Agriculture. Nutr Dev 9:678-690

Oviasogie PO, Aghimien AE (2003) Macronutrient status and speciation of $\mathrm{Cu}, \mathrm{Fe}, \mathrm{Zn}$ and $\mathrm{Pb}$ in soil containing palm oil mill effluent. Glob J Pure Appl Sci 9:71-80

Peveling R, McWilliam AN, Nagel P et al (2003) Impact of locust control on harvester termites and endemic vertebrate predators in Madagascar. J Appl Ecol 40:729-741

Pomeroy DE (1976) Studies of population of large termite mounds in Uganda. Ecol Entomol $1: 49-61$

Quansah C, Fening JO, Ampontuah EO et al (2001) Potential of Chromolaena odorata, Panicum maximum and Pueraria phaseoloides as nutrient sources and organic matter amendments for soil fertility maintenance in Ghana. Biol Agric Hortic 19:101-113

Richard JF, Ait-Baddi G, Costa C et al (2006) Comparative study of humic acids of the mound of a wood-feeding termite and of the litter directly below in the Amazon river delta. Chem Ecol 22(3):201-209

Roder W, Phengchanh S, Keoboualapha B et al (1995) Chromolaena odorata in slash-and-burn rice systems of Northern Laos. Agrofor Syst 31:79-92

Rouland-Lefèvre C (2011) Termites as pests of agriculture. In: Bignell DE et al (eds) Biology of termites: a modern synthesis. Springer Science + Business Media B.V, Dordrecht, pp 499-517

Sánchez-Bayo F (2014) The trouble with neonicotinoids: chronic exposure to widely used insecticides kills bees and many other invertebrates. Science 346(6211):806-807

Sartie A, Franco J, Asiedu R (2012) Phenotypic analysis of tuber yield- and maturity-related traits in white yam (Dioscorea rotundata). Afr J Biotechnol 1:3964-3975

Sekamatte MB, Okwakol MJN (2007) The present knowledge on soil pests and pathogens in Uganda. Afri J Ecol 45(2):9-19

Shell Petroleum Development Company of Nigeria Limited (SPDC) (1998) Environmental impact assessment of Obigbo Node associated gas gathering project: final report by Tial Trade Limited, Nigeria

Sileshi GW, Nyeko P, Nkunika POY, Sekamatte BM, Akinnifesi FK, Ajayi OC (2009) Integrating ethno-ecological and scientific knowledge of termites for sustainable termite management and human welfare in Africa. Ecol Soc 14(1):48

Slingo JM, Challinor AJ, Hoskins BJ, Wheeler TR (2005) Food crops in a changing climate. Philos Trans R Soc B Biol Sci 360:1983-1989

Šmilauer P, Lepš J (2014) Multivariate analysis of ecological data using CANOCO 5, 2nd edn. Cambridge University Press, Cambridge

Sumi H, Kunito T, Ishikawa Y et al (2014) Plant roots influence microbial activities as well as cadmium and zinc fractions in metal-contaminated soil. Chem Ecol 31(2):105-110

Tian G, Kolawole OG, Kang BT et al (2000) Nitrogen fertilizer replacement indexes of legume cover crops in the derived savannah of West Africa. Plant Soil 224:287-296

Tondoh JE, Kone AW, N'Dri JK et al (2013) Changes in soil quality after subsequent establishment of Chromolaena odorata fallows in humid savannahs, Ivory Coast. Catena 101:99-107 
UNEP (2000) FAO and Global IPM facility expert group on termite biology and management. United Nations Environmental Programme: chemicals finding alternatives to Persistent Organic Pollutants (POPs) for termite management. http://www.chem.unep.ch/Publi cations/pdf/Alterna tives-termitefulldocument.pdf

Veldhuis MP, Laso FJ, Olff $\mathrm{H}$ et al (2017) Termites promote resistance of decomposition to spatiotemporal variability in rainfall. Ecology 98:467-477

Wood TG (1995) The agricultural importance of termites in the tropics. Agric Zool Rev 7:117-155

Wu TY, Mohammad AW, Jahim JM et al (2009) A holistic approach to managing palm oil effluent (POME): Biotechnological advances in the sustainable reuse of POME. Biotechnol Adv 27:40-52

Zimmerman PR, Greenberg JP (1983) Termites and methane. Nature 302:354-355

Open Access This chapter is licensed under the terms of the Creative Commons Attribution 4.0 International License (http://creativecommons.org/licenses/by/4.0/), which permits use, sharing, adaptation, distribution and reproduction in any medium or format, as long as you give appropriate credit to the original author(s) and the source, provide a link to the Creative Commons license and indicate if changes were made.

The images or other third party material in this chapter are included in the chapter's Creative Commons license, unless indicated otherwise in a credit line to the material. If material is not included in the chapter's Creative Commons license and your intended use is not permitted by statutory regulation or exceeds the permitted use, you will need to obtain permission directly from the copyright holder.

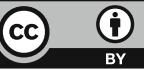

